J. Soc. Brew. Japan, 1976, Vol. 71, No. 12, p. $992 \sim$ p. 994

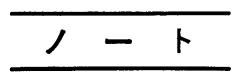

\title{
大阪国税局管内の市販清酒の分析結果について（その 2)
}

\author{
製造方法の判別
}

\section{大阪国税局鑑定官室}

昭和 51 年 7 月 12 日受理

\section{は じめに}

近年, 純米醸造酒や本醸造酒等が製造, 販売されるよ らになり，製造方法の表示基準も定められているから， 一般の清酒とこれら製造方法の異なる清酒相互間を化学 分析により判別できるかどらか検討する事も必要と思わ れる。前報1)で市販清酒の現況等について報告した。そ れによれば酸度, アミノ酸度も製造方法により若干の差 が認められるが, 判別に利用できるほどではない。また， これらは, 使用原材料以外の要因によって大きく変動す るので判別の指標とするには不適当である。そこで本報 では製造方法による差が比較的顕著で，すろみ醗酵過程 等による変化が少なく, 判別法として利用できると期待 される直糖とエキス分の比率, 及び $n-\mathrm{PrOH}, i-\mathrm{BuOH}$, $i-\mathrm{AmOH}$ (以下高級アルコールという) のエチルアルコ ールに対する割合を取り上げ，検討したのでその結果を 報告する。

\section{実 験 方 法}

\section{(1) 試 料}

大阪国税局管内の製造場より昭和 50 年 10 月に採取し た市販清酒を分析試料とした。試料の区分は, 製造方法 の表示により行ない, 表示のないものについては級別に 分けた。

（2）分析方法

(1) エチルアルコール，直糖，エキス分

国税庁所定分析法によった。

(2) 高級アルコール

蒸留一ガスクロマトグラフィーを採用した。すなわち 国税庁所定分析法 3-4-1（アルコールの測定）の操作に より得られる蒸留液を内標準法で定量した。ただし内標 準物質には $n-\mathrm{BuOH}$ を使用した。蒸留液の採取量と高 級アルコールの回収程度の関係は第 1 図のとおりであ り, 採取量を $50 \mathrm{~m} l$ 以上にすれば回収でさる事がわか る。なお，合成清酒による回収試験結果は第 1 表のとお りである。

\begin{tabular}{ccl}
\multicolumn{3}{c}{ ガスクロマトグラフィー条件 } \\
機 & 種 & 島津 $\mathrm{GC}-5 \mathrm{~A}$ \\
カ & ム & ステンレス製 $2 \mathrm{~m}$ \\
\multicolumn{2}{c}{ カラム充填剤 } & PEG $1000,5 \%, 60 \sim 80 \mathrm{mesh}$ \\
流 & 量 & $\mathrm{N}_{2} 40 \mathrm{~m} l / \mathrm{min}, \mathrm{H}_{2} 35 \mathrm{ml} / \mathrm{min}$ \\
& & 空気 $0.9 l / \mathrm{min}$ \\
温 & 度 & カラム $90^{\circ} \mathrm{C}$ \\
& & 検出器, 試料気化室 $200^{\circ} \mathrm{C}$ \\
感 & 度 & Sens. $10^{2}$, Range 4 \\
試 & 料 & $5 \mu l$
\end{tabular}

\section{結果および考察}

\section{（1）直糖とエキス分の比率}

直糖，エキス分および直糖/エキス分は，第 $2 ， 3 ， 4$ 表 のと拈りであった。直糖/エキス分は, 純米醸造酒が一

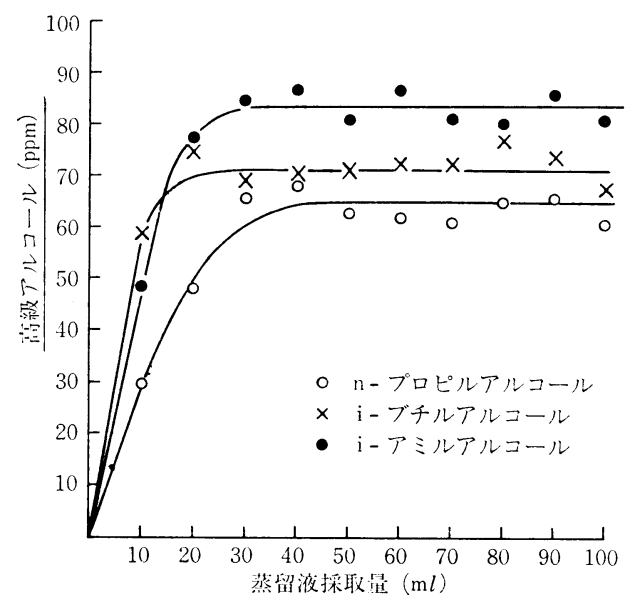

第1図 高級アルコール回収量

第 1 表 合成清酒による回収試験

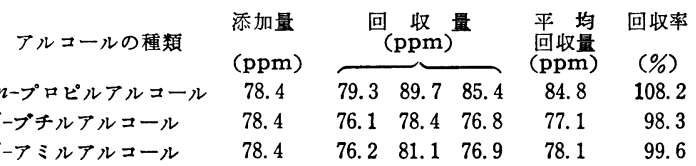


第 2 表 種々の清酒中の直糖含量 $(\mathrm{g} / 100 \mathrm{~m} l)$

\begin{tabular}{|c|c|c|c|c|c|c|c|}
\hline & $n$ & $\bar{x}$ & $\max$ & $\min$ & $\sigma$ & $\sigma / \bar{x} \times 100$ \\
\hline \multicolumn{2}{|c|}{ 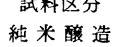 } & 20 & 2. 99 & 4.00 & 2. 26 & 0.429 & 14.35 \\
\hline 本 醉 & 造 & 39 & 3. 40 & 4.72 & 2. 42 & 0.487 & 14.32 \\
\hline 特 & 級 & 17 & 3. 58 & 4. 30 & 2.74 & 0.391 & 10.92 \\
\hline & 級 & 17 & 4.01 & 4. 64 & 3.68 & 0.240 & 5.99 \\
\hline & 級 & 30 & 3. 82 & 4.58 & 3.12 & 0.274 & 7.17 \\
\hline
\end{tabular}

第 3 表 種々の清酒中のエキス分含量 $(\mathrm{g} / 100 \mathrm{ml})$

\begin{tabular}{|c|c|c|c|c|c|c|c|}
\hline & \multirow{2}{*}{$\begin{array}{l}n \\
20\end{array}$} & \multirow{2}{*}{$\begin{array}{c}\bar{x} \\
6.14\end{array}$} & \multirow{3}{*}{$\begin{array}{r}\max \\
7.18 \\
7.62\end{array}$} & \multirow{3}{*}{$\begin{array}{l}\min \\
5.28 \\
4.82\end{array}$} & \multirow{3}{*}{$\begin{array}{c}\sigma \\
0.472 \\
0.541\end{array}$} & \multirow{2}{*}{$\begin{array}{r}\sigma / \bar{x} \times 100 \\
7.69\end{array}$} \\
\hline & & & & & & \\
\hline \multicolumn{2}{|c|}{ 本米酸造酸 } & \multirow{2}{*}{$\begin{array}{l}39 \\
17\end{array}$} & \multirow{2}{*}{$\begin{array}{l}0.16 \\
6.42\end{array}$} & & & & 8.78 \\
\hline \multicolumn{2}{|c|}{$\begin{array}{ll}\text { 本 } & \text { 酸 } \\
\text { 寺 } & \text { 造 } \\
& \text { 級 }\end{array}$} & & & 6.74 & 5.58 & & 5.23 \\
\hline \multicolumn{2}{|c|}{$\begin{array}{l}\text { 級 } \\
\text { - } \\
\text { 級 }\end{array}$} & 17 & 6.45 & 6.97 & 5.8 & 0.271 & 4. 20 \\
\hline \multicolumn{2}{|r|}{ 級 } & 30 & 6.05 & 6.79 & 5.20 & 0.335 & 5.5 \\
\hline
\end{tabular}

第 4 表 種々の清酒中の直糖分/エキス分

\begin{tabular}{|c|c|c|c|c|c|c|c|}
\hline & $n$ & $\bar{x}$ & $\max$ & $\min$ & $\sigma$ & $\sigma / \bar{x} \times 100$ \\
\hline \multicolumn{2}{|c|}{ 純米䁵造 } & 20 & 0.49 & 0.56 & 0.42 & 0.044 & 8.98 \\
\hline 本 醇 & 造 & 39 & 0.56 & 0.67 & 0.40 & 0.053 & 9.46 \\
\hline 持 & 級 & 17 & 0.56 & 0.64 & 0.49 & 0.041 & 7.32 \\
\hline- & 粐 & 17 & 0.62 & 0.67 & 0.58 & 0.023 & 3. 71 \\
\hline & 級 & 30 & 0.63 & 0.68 & 0.58 & 0.029 & 4.60 \\
\hline
\end{tabular}

番低く，次いで本醇造酒と特級酒がほぼ同じで，一級酒 と二級酒が最も高い値を示した。これらの差は, 四段仕 込や三増酒の混和の有無, 量により生じるものと推察さ れる。特級酒と本醸造酒がほぼ同じ值を示したのは, 試 料に供した特級酒がほとんどすべて糖類無添加表示のも のであり，実質的に本醸造と差がないためである。純米

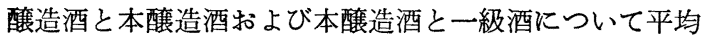
值の差の検定を行なったところ，それぞれ $t=5.007, t$ $=5.059$ となり，いずれも危険率 $1 \%$ で有意差があっ た。

\section{（2）エチルアルコールに対する高級アルコールの割 合}

第 $5,6,7,8$ 表にエチルアルコール 1 度当りの高級ア ルコールの平均值等を示す。各高級アルコールとも純米 醸造酒が最も多く, 以下本醇造酒, 一級酒の順である。 高級アルコール生成量は, 酵母の種類, 精米歩合や酘酵 経過等によりかなり変動するといわれているし 2 5)，ま た火入 ${ }^{6)}$ や活性炭素処理による減少もあるが，今回の調 査対象酒については，アル添又は調味液添加による希釈 の影響の方がかなり大きいようである。各製造方法内に おけるバラッキを $\sigma / \bar{x} \times 100$ で比較すると，いずれの高 級アルコールとも本醇造酒が最も小さい。これは, アル コール使用法等の製造方法が割合一定しているためと思 われる。

試料ごとに $n-\mathrm{PrOH}$ と $i-\mathrm{AmOH}$ を比べると一級酒, 本䤑造酒ではすべて $i-\mathrm{AmOH}$ の方が多いが，純米の中 には $n-\mathrm{PrOH}$ の方が多いものがあった。

判別が確実であるためには, 製造方法間の平均值の差
第 5 表 エチルアルコール1度あたりの $n$-プロピ ルアルコール ( $\mathrm{ppm} /$ 度)

\begin{tabular}{|c|c|c|c|c|c|c|}
\hline 試料区分 & $n$ & $\bar{x}$ & $\max$ & $\min$ & $\sigma$ & $\sigma / \bar{x} \times 100$ \\
\hline 純米醇 造 & 15 & 6.12 & 7.6 & 4.3 & 0.958 & 15.7 \\
\hline 本酸造 & 21 & 4. 78 & 6.0 & 3.7 & 0.668 & 14.0 \\
\hline 一 & 17 & 3.71 & 4.9 & 2.8 & 0.551 & 14.9 \\
\hline
\end{tabular}

第 6 表 エチルアルコール 1 度あたりの $i$-ブチル アルコール $(\mathrm{ppm} /$ 度 $)$

\begin{tabular}{|c|c|c|c|c|c|c|}
\hline 哉料区分 & $n$ & $\bar{x}$ & $\max$ & $\min$ & $\sigma$ & $\sigma / \bar{x} \times 100$ \\
\hline 純米醇 造 & 15 & 3.68 & 5.3 & 2.7 & 0.712 & 19.4 \\
\hline 本 酸 & 21 & 3.14 & 4.3 & 2.4 & 0.534 & 17.0 \\
\hline 級 & 17 & 2.75 & 4.4 & 1.7 & 0.718 & 26. \\
\hline
\end{tabular}

第 7 表 エチルアルコール 1 度あたりの $i$-アミル アルコール $(\mathrm{ppm} /$ 度 $)$

\begin{tabular}{|c|c|c|c|c|c|c|}
\hline 試料区分 & $n$ & $\bar{x}$ & $\max$ & $\min$ & $\sigma$ & $\sigma / \bar{x} \times 100$ \\
\hline 純米酬造 & 15 & 7.91 & 9.6 & 3.9 & 1.664 & 21.0 \\
\hline 本 䤄 & 21 & 6.80 & 8.1 & 4.9 & 0.775 & 11.4 \\
\hline 一 & 17 & 5.64 & 8.0 & 4.3 & 0.949 & 16.8 \\
\hline
\end{tabular}

第 8 表 エチルフルコール 1 度あたりの高級アルコ ール合計値 $(\mathrm{ppm} /$ 度)

\begin{tabular}{|c|c|c|c|c|c|c|}
\hline 試料区分 & $n$ & $\bar{x}$ & $\max$ & $\min$ & $\sigma$ & $\sigma / \bar{x} \times 100$ \\
\hline 純米賈造 & 15 & 17.71 & 20.4 & 13.5 & 2. 241 & 12.7 \\
\hline 本醸 造 & 21 & 14.72 & 17.3 & 11.4 & 1.497 & 10.2 \\
\hline 級 & 17 & 12.09 & 15.2 & 9.6 & 1.623 & 13. \\
\hline
\end{tabular}

が比較する製造方法両者のバラッキに比べ十分大きい 事, 即ち $\bar{x}_{1}-\bar{x}_{2} / \sigma_{1}+\sigma_{2}$ が大きい程よい。 $n-\mathrm{PrOH}$ のそ れは, 純米醸造酒と本醸造酒との間が 0.824 , 本醸造酒 と一般醸造酒が 0.878 で必ずしも十分ではないが, 高級 アルコールの中では一番大きい。また，直糖/エキス分 の場合は, 純米醇造酒と本醸造酒との間が 0.722 , 本醇 造酒と一級酒が 0.789 で $n-\mathrm{PrOH}$ よりはやや小さい。

(3) 直糖とエキス分の比率と高級アルコールの関係 直糖/エキス分と $n-\mathrm{PrOH} / \mathrm{EtOH}$ の散布図を第 2 図に 示す。これより相関係数を求めると $r=0.585$ となり, 危険率 $1 \%$ で相関関係がある。従って, 製造方法の見当 をつけるためには両者のいずれでも良く，分析の容易な

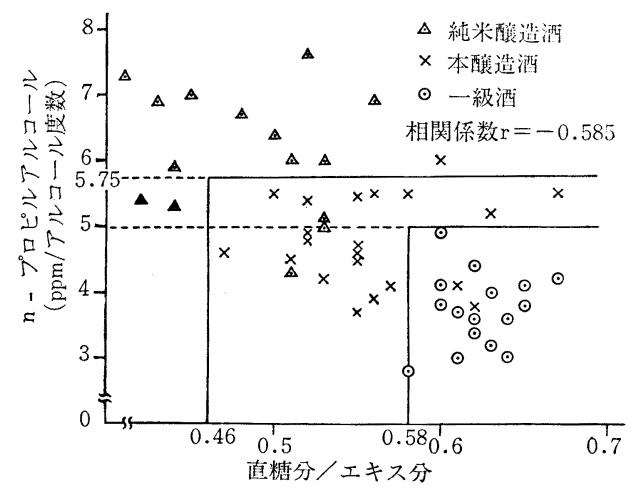

第 2 図直糖分/エキス分と $n$-プロピルアルコール の分布 
方を選べばよいといえるが，両者の測定値の動きは，全 く同一ではないので, 両者を加味した方がより確実であ る。第 2 図の境界線は任意に入れたるのにすぎないが, およそこのあたりにそれぞれの製造法の境界があり，そ れに従って判断してる誤る危険はあまり多くないと思わ れる。

$$
\text { ま と め }
$$

市販清酒の製造方法の推定が可能な分析法として, 直 糖とエキス分の比率及び高級アルコールを検討した。高 級アルコールも直糖とエキス分の比率と同様判別に利用
できるが，なかでも $n$-PrOH が最もすぐれていた。ま た，両者を組み合せる事により一層確実な推定ができる

事がわかった。

文献

1) 大岅国梲局籍定官室：本誌，71，(1976）

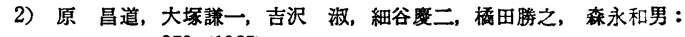
酸工, 43, 873 (1965)

3）小泉武夫：本誌，63，446 (1968)

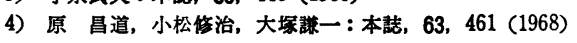

5）小泉武夫, 武石正久: 本誌, 66, 251 (1971)

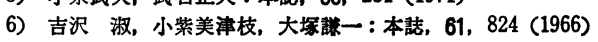

